\title{
International Journal of Informatics, Information System and Computer Engineering
}

\section{Sustainability Policy in Indonesia: Case Study Economic Structure and Determinants in Banjar Municipality}

Agus Supriyadi ${ }^{1}$, Tao Wang ${ }^{2}$, Melda Ria Juwita ${ }^{3}$, Rayhan Gunaningrat ${ }^{4}$, Susi Safitri ${ }^{5}$, Giuseppe T Cirella ${ }^{6}$

1,2,3,5The School of Geography, Nanjing Normal University, Nanjing 210023, China

4Program Studi Manajemen, Fakultas Hukum dan Bisnis, Universitas Duta Bangsa, Indonesia

${ }^{6}$ Faculty of Economics, University of Gdansk, 81-824 Sopot, Poland

Correspondence: E-mail: agus_dea@yahoo.com

\section{A B S T R A C T S}

In response to governance shift in Indonesia, a heavy burden of responsibility is placed on local authorities to act in the best interest of its citizenry. This study examined evidence of local government policy, economic structure, and economic growth in the new autonomous city of Banjar Municipality, West Java Province, Indonesia and assessed determinants of regional transformation. The methodology used location quotient, analysis, shift-share analysis, and ordinary least square regression analysis. The findings revealed in the ten-year period of the study on agriculture, business trade, accommodation, other sectors and public service dominated the structure of the economy. In terms of the authority, the Municipality's policy of sustainability is aimed at protecting the traditional market and developing local road infrastructure-contributing to its economic growth. Sustainability-oriented policies are designed to stress order, control, and accelerate economic activities which regional authorities sometimes considering them as challenging due to transitional requirements and demands.

\author{
A R T I C L E I N FO \\ Article History: \\ Received 10 May 2021 \\ Revised 20 May 2021 \\ Accepted 25 May 2021 \\ Available online 26 June 2021
}

Keywords: Sustainable development, Economic growth, Autonomy city, Gevernance, Indonesia. 


\section{INTRODUCTION}

Indonesia is one of the most populous and largest archipelagic countries in the world, with multi-ethnic, multi-cultural, and various regional languages facing a number of management-oriented challenges. Since the economic crisis of 1997 hampered most of Asia, many countries have taken action in response to the condition, including Indonesia. The crisis led the Indonesian government to implement transformative centralized to decentralization action, where some of the state powers and resources were transferred to the lower level of government, i.e., at the provincial- and municipal-level. In 1999, a policy known as regional autonomy was implemented, converting the country into the largest worldwide laboratory, to test out the decentralization experiment (Miller, 2013). As a response, the success of this policy move on economic and income growth still depends on the local government's response to the market and the orientation of economic development Asia-wide (Asian Development Bank, 2010). A significant issue that usually arises in a number of countries is the dependency and burden of local governments highly reliant on central government transfer (i.e., by not maximizing local resources and revenue) (Masaki, 2019; Kelly, 2012; Oates, 1993).

Evidence from Ghana in 2004 has shown that higher external transfers toward local authority does not encourage the increase of local revenue. This condition contradicts one of the fundamental motivations of the decentralization policy, where the effectiveness and efficiency of allocated local resources (i.e., by the local authority), can be outweighed by local knowhow (e.g., indigenous knowledge and community needs) (Mogues \& Benin,
2012). The purpose for regional development is a bottom-up approach to improving the communityin terms of fiscal decentralization by enhancing economic efficiency and social wellbeing (Oates, 1993). A useful example from China illustrates cities with higher gross regional domestic product (GRDP) tend to be more inclusive, i.e., cities with a larger population and higher GRDP per capita have a significant industrial sector contributing to the gap of inclusiveness between the high and low skilled ( $\mathrm{Hu} \&$ Wang, 2019). Prior research has also shown that in terms of economic growth, human capital contributes significantly compared to fixed capital investment (Liu et al., 2018).

As a result of Indonesia's reformation, regional autonomy was followed up by a number of responsibilities in which local governments highly accommodating their new-found power. The system, however, brought forth both opportunities and challenges (Miller, 2013; Sondakh \& Jones, 2003). The transferability of authority, to date, directly associated local governments with the underlying objectives of poverty reduction, public service improvement, and public participation - something the central government has also deemed as critical (Suryahadi et al., 2012). Banjar Municipality an autonomous city located in West Java Province with a population of more than 200,000 inhabitants. The city was allocated as one of the new autonomous cities established at the implementation of the regional autonomy policy - nationwide. Since its inauguration in 2002, there has been massive development in terms of infrastructure and public service. In 2010, based on an assessment of 33 indicators, with four main factors of assessment (i.e., community welfare, governance, public services, and regional competitiveness), 
Banjar Municipality has achieved awardlike success as the second most thriving autonomous city in West Java Province. Despite the location of the city, at the east border of West Java Province and faraway from a metropolitan city, its performance in accordance with good governance has assisted in piecing together a highly productive government output. Positive economic growth of the city, however, has never reached more than $5.6 \%$ (BPS-Statistic of Banjar Municipality, 2017) which has some cause for concern - especially in terms of policymaking. Since its establishment, research into its leading sectors as well as economic structure, i.e., concerning economic growth, and how the municipality by protecting the traditional market has not been done.

Evidence of previous research from the State of Michigan-and municipalities within it-shows incentive-based policies that play an important role in employment and in establishing new businesses. These policies have been considered one of the most successful strategies in the postcrisis era (Drucker et al., 2019). Based on this economic development, we consider local regulation and analyze independent variables to best calculate and explain economic growth in Banjar Municipality (see Fig. 1).

Banjar Municipality's uniqueness, as a city, was inaugurated by the Minister of the Home Affairs as one a municipality that administratively controls not only urban but also rural villages. This important fact internalized our research to focus on providing important guidance and recommendations in this context. Urban villages (kelurahan) are territorial units occupied by a number of residents, at the lowest governmental level, are organized directly under the district head and have no rights to household ownership. The main characteristic of the urban village is that it is led by civil servants and not chosen by the people. Local authorities can postpone a permit, for example, when investigating developmental ideas and projects. As such, a modernized market was introduced to help with a lagging traditional market during the economic crisis - noted by trade sectors indicators and revived vital points in economic development.

The regional autonomy policy in Indonesia successfully spurred research interest in trend, impact, determinant, and impact on economic growth; however, limited studies have looked at how these new autonomous cities operate independently. The paper conducts critical research into better understanding the problems and challenges of the state of the art of Banjar Municipality and presents future solutions. We fill in a number of gaps, in terms of sectoral information and economic structure by relating our findings to economic growth in the Municipality. The scope of the research will benefit policymakers and city planners alike as well as scholars in helping guide and benchmark future works. A breakdown of the paper is structured as follows: Section 2 is a literature review, Section 3 contains the methods, Section 4 illustrates the results, Section 5 elucidates a discussion on impact and development, and Section 6 presents the conclusions and policy implications. 


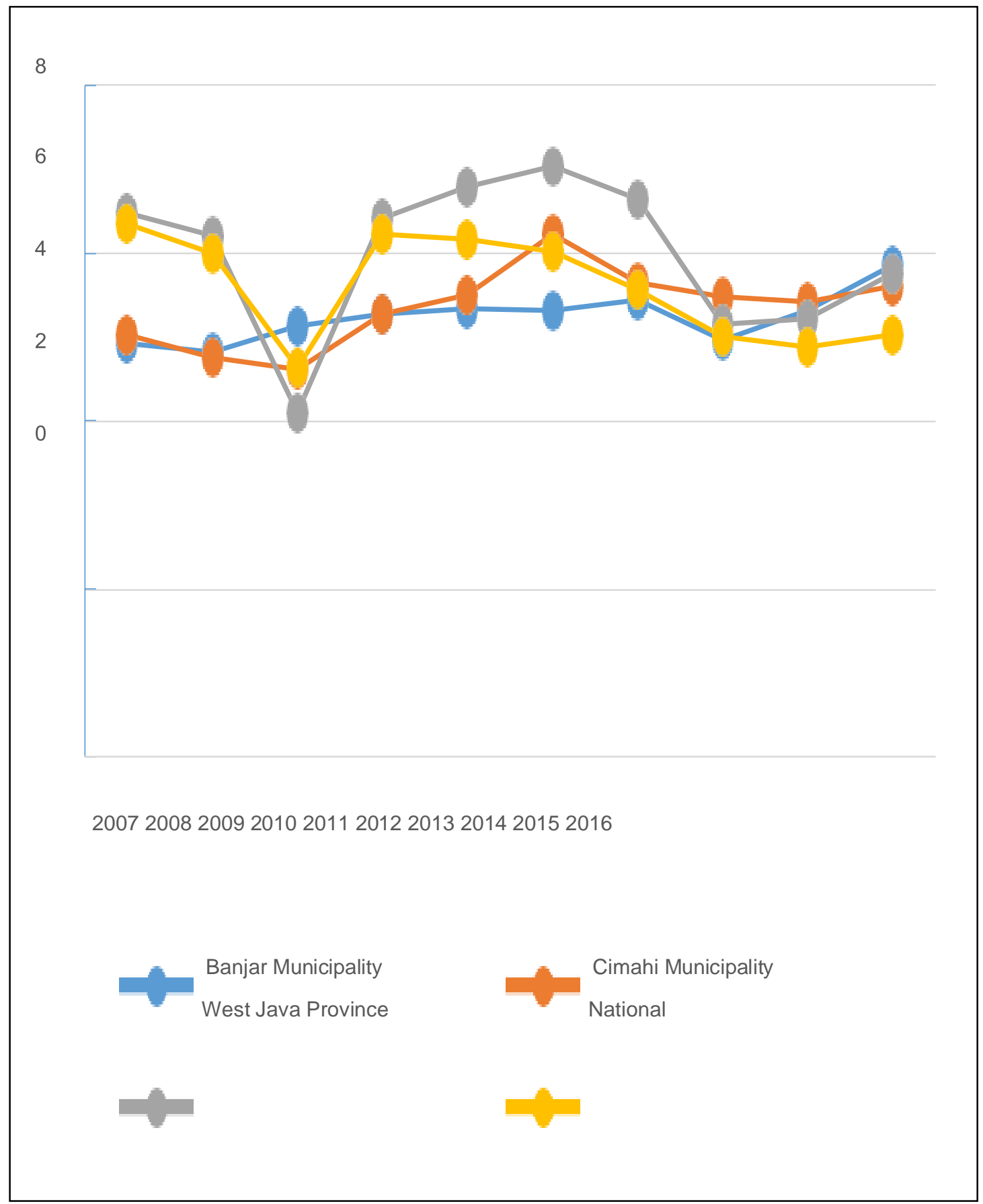

Fig. 1. Economic Growth of Banjar Municipality Compared with Regional and National Levels, 2007-2016.

\section{THEORETICAL FRAMEWORK}

\subsection{Globalization and Regional Autonomy}

The restructuring of Indonesia's economy is the primary factor for its economic growth (Lankauskienè \& Tvaronavičienė, 2013). Lessons from China and India play an important role in the region in terms of labor and influence (Mallick, 2017). This mobility assert transformative effects during the period between 1970 to 1990; as such, structural changes on average had not been conducive to productivity growth (Fegerberg, 2000). Globalization and the development of technology in the twenty-first century significantly 
changed the global landscape and palpably contributed to its transformation. A focus on economic development is now transforming job growth and businessto job creation, business growth, and income growth (i.e., factors that are the typical and reasonable within Indonesia's economic development policy). Nonetheless, broader social and environmental improvements parallel the strengthened economy (Moore et al., 2006). Regional autonomy came into play, around the world, as a possible solution to solving regional economic problems. Decentralization theory, as the foundation of regional autonomy policies, leans toward a robustness in comparison to a centralized country (Paganelli, 2006). Compelling empirical evidence from Indonesia, since regional autonomy was implemented to 2015, showed regional revenue (i.e., nationwide) increased by $374 \%$, a significant impact and confidante with the policy (Suryani, 2015). Key factors of economic growth are discussed by Wagner's theory of "Law of Expanding State Expenditure" in which increasing per-person income in correlation with increases in state expenditure (Sobari, 2011; Wagner, 1890; Suryani, 2015) can prove to be beneficial. Research conducted using location quotient (LQ) and shift share analysis (SSA) in Banyuwangi Regency in East Java Province revealed that one overpowering sector does not necessarily give overarching value to a regional economy (Khusaini, 2015) due to a lack of economic balance and sustainability - cutting local competitiveness and creating monopolylike circumstances (Akib et al., 2019). As such, it is essential to consider the quality of human capital, including: wellbeing, distance and travel time to work, transportation service, road and infrastructure condition, and other supporting amenities (Endaryanto et al., 2015).

\subsection{Regional Economics and Gross Regional Domestic Product (GRDP)}

Dunn discussed a statistic approach to understanding regional economics and its contributive effects via differing sectors' contribution to economic growth (Dunn, 1960). His research continues to influence researchers in various fields, including a number of studies, that used SSA to explain certain economic phenomena in a community (e.g., regional employment development trend and regional growth (Goschin, 2014; Rigby \& Anderson, 1993). Other examples of SSA include a Spanish study that revealed higher competitiveness in agriculture and construction sectors, while industry and service had the opposite effect (Fernández \& Menéndez, 2005). Three components that are widely used include: (1) national and regional share components, (2) industrial mix components and proportional shift, and (3) differential and competitive share components (Evans, 2008; Noisirifan, 2018; Morrisey, 2014).

In a new paradigm of regional economic theory there is a basic developmental shift (i.e., transformation) from development economic sectors to economic institutions (Kifli \& Umami, 2017). In the globalization era, autonomous cities makeup one form of the implemented economic institutions' framing. Despite its critics, the use of gross domestic product (GDP) as a measurement of human wellbeing has held fast for half a century-accepted as the standard measure for a country's progress (Contanza et al., 2009). In the local economy, GRDP generally uses 
indicators that measure macroeconomic activity-locally (Andayani, 2018; Feriyanto, 2014). Several studies, however, used GRDP and revealed how leading local products and spatial economic contributions (i.e., regionally and nationally) showed meaningful and reciprocal economic results (Kristiawan et al.,2016; Kifli \& Umami, 2017) ; Endaryanto et al., 2015). Johnston and Huggins also highlighted that a variety of industrial structures can significantly affect the dynamism of regional growth (Johnston \& Huggins, 2018).

The implementation of regional autonomy in Indonesia signaled new authority to control and develop their local needs. Prior research from China showed how low quality of rural roads can significantly influence economic growth (i.e., in a negative matter compared towell-developed ones) (Fan \& Chan-kang, 2005). Hence, built infrastructure policy is one important way of maintaining positive economic development. In terms of sustainable economic growth, investment in education is also one key policy that should be considered for local governments (Liao et al., 2019; Sukamdi, 2014). Evidence from the 1970s and 1980s show a positive correlation between government expenditure and economic growth-investment playing a large part of the growth (Bose et al., 2007). Another variable that contributes significantly to the expansion of an economy is its labor force, as can be seen in the United States from 1948 to 2001 with an increase of 1.7 $\%$ per annum to the average annual growth of potential real GDP (Daly \& Regev, 2007). This type of advancement also occurred in China between 1990 and 2009 where its economy stabilized its growth by promoting and improving labor quality and consumption capabilities (Zhu et al., 2011). Reinforcing this viewpoint, Nosier and El-Karamani stress a series of variables such as education, health, government consumption, and trade openness as having a non- monotonic effect on growth through education and physical capital accumulation via labor (Nosier \& El-Karamani, 2018). Moreover, resolving labor force and unemployment problems for urban and rural areas will require different parametric expertise (i.e., urban policies should focus on service sectors while rural should be on agricultural ones) (Suryadarma et al., 2013). It is also essential for a country to invest in human capital (Ali et al., 2018) to stimulate economic activity for best policymaking practices-developed via appropriate regulatory and local knowhow (Fisher, 1997; Romyen et al., 2019). From this outlook, our paper's scope prepares sectoral-based research that measures Banjar Municipality's transition as an autonomous city and bestows future economic requirements and demands for the betterment of Indonesia and its policy development.

\section{DATA SOURCE AND METHODS}

\subsection{Data Source}

This research examines leading sectors, economic structure, and GRDP in the new autonomous city of Banjar Municipality, Indonesia. It is located on the east border of West Java Province. The Municipality's population has grown from 160,810 in 2002 to 202, 362 in 2017 (BPS-Statistic of Banjar Municipality, 2017). The city is expected to grow in terms of industrial development, trade, service, and tourism via the east region of West Java. Since its inauguration, the Municipality has had to uniquely configure its authority over its four districts (i.e., kecamatan) as well as its 22 villages and urban villages (i.e., desa and 
kelurahan). This makeup has fashioned Banjar Municipality as one of the new autonomous cities administratively as a city and municipality that also manages village and urban village areas. Since it was established the Municipality's revenue has been dominated by trade, hotels, and restaurants.

The method of the data collected for this study utilized two methods. First, we collected online data from BPS-Statistics Banjar Municipality's website and, second, we directly requested the data from the local authorities, including: Regional Planning and Development Agency of Banjar Municipality and Regional Financial and Asset Agency. The data period spans from 2007 to 2016 . We utilize GRDP sector data from BPSStatistics Banjar Municipality which is grouped and categorized based on the System of National Accounts 1993 and Indonesian Standard Industrial Classification (i.e., Klasifikasi Lapangan Usaha Indonesia) 1990 (BPS, 2017).

The land use map of Banjar Municipality in 2006 acts as a starting point for this research (see Fig. 2).
As can be seen in figure 2 agricultural areas dominate almost in many areas. The center of urban area growth is still dominated in the city center, but the agglomeration of urban areas is divided into two regions namely in the Banjar District and the Langensari District. This is in line with the concept planned by the local authority that expects two centers of economic activity to grow.

We further adjust via the International Standard Industrial Classification for all economic activities which were released by United Nations sources. The GRDP sectors include: agriculture, mining and quarry, construction and building, processing industry, electricity, gas and water, transportation and communication, trade, hotels and restaurants, and service sectors-all considered key economic activities (Arent et al., 2015). Variable symbols, descriptions, and data sources are shown in Table 1. 


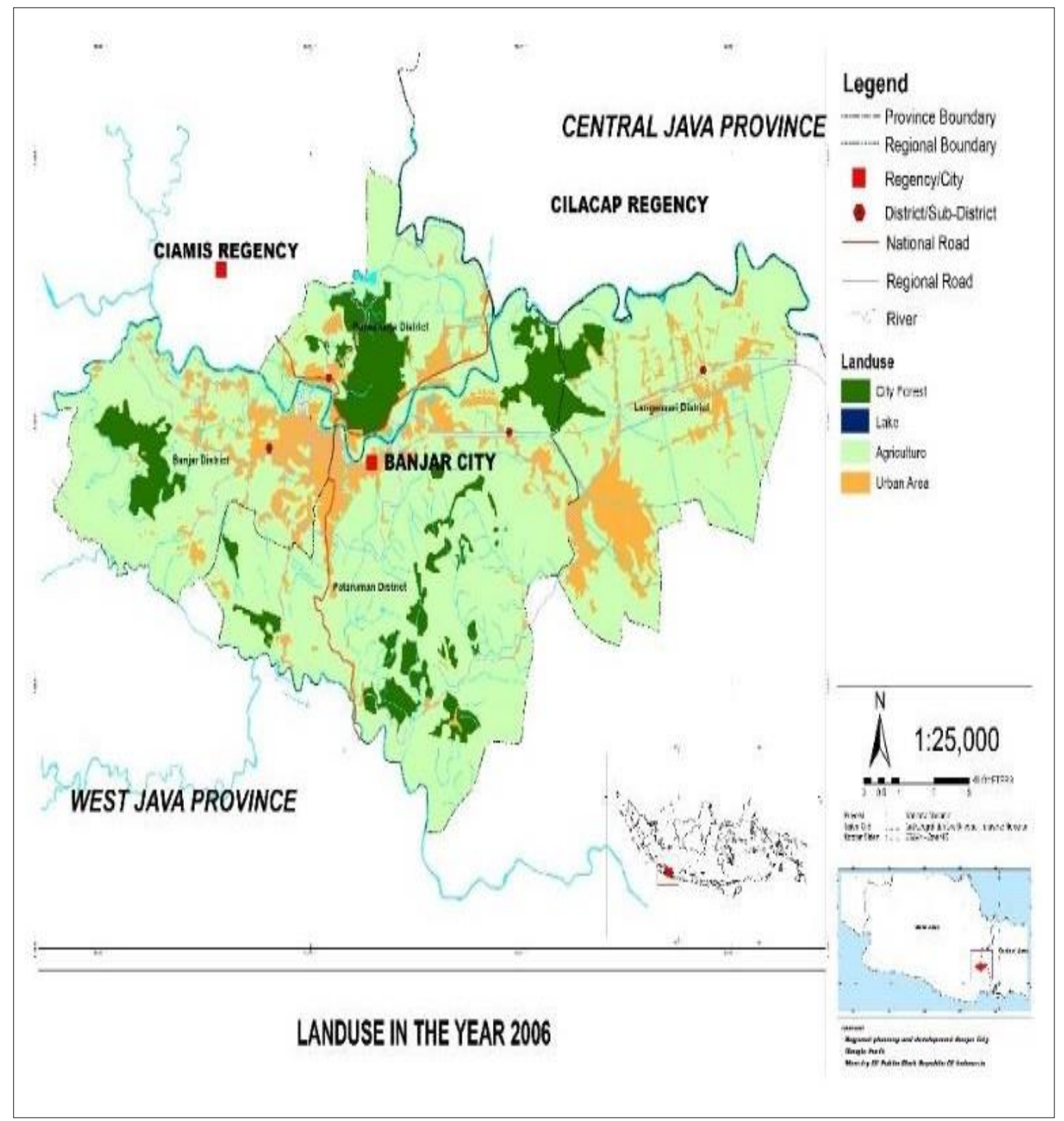

Fig. 2. Land Use Map of Banjar Municipality (Supriyadi et al., 2020)) 
Table 1. Variable and Data Source

\begin{tabular}{|c|c|c|c|}
\hline Variable name & Variable & Variable description & Data source \\
\hline $\begin{array}{l}\text { Agriculture, } \\
\text { livestock, } \\
\text { forestry, and } \\
\text { fishery }\end{array}$ & Agr & $\begin{array}{l}\text { Includes farm food crops, } \\
\text { non-food } \\
\text { crops, livestock and product, } \\
\text { forestry, and fishery }\end{array}$ & $\begin{array}{l}\text { BPS-Statistics Banjar } \\
\text { Municipality }\end{array}$ \\
\hline $\begin{array}{l}\text { Mining and } \\
\text { quarrying }\end{array}$ & $\mathrm{MC}$ & $\begin{array}{l}\text { Includes non-oil gas and } \\
\text { quarrying }\end{array}$ & $\begin{array}{l}\text { BPS-Statistics Banjar } \\
\text { Municipality }\end{array}$ \\
\hline $\begin{array}{l}\text { Manufacture } \\
\text { industry }\end{array}$ & MI & $\begin{array}{l}\text { Non-oil and gas } \\
\text { manufacturing }\end{array}$ & $\begin{array}{l}\text { BPS-Statistics Banjar } \\
\text { Municipality }\end{array}$ \\
\hline $\begin{array}{l}\text { Electricity, gas, } \\
\text { water supply, } \\
\text { and } \\
\text { water treatment }\end{array}$ & EGW & $\begin{array}{l}\text { Electricity, gas water supply, } \\
\text { and treatment consumptions }\end{array}$ & $\begin{array}{l}\text { BPS-Statistics Banjar } \\
\text { Municipality }\end{array}$ \\
\hline $\begin{array}{l}\text { Construction and } \\
\text { building }\end{array}$ & Cons & Construction activity & $\begin{array}{l}\text { BPS-Statistics Banjar } \\
\text { Municipality }\end{array}$ \\
\hline $\begin{array}{l}\text { Trade, } \\
\text { accommodation, } \\
\text { and food business }\end{array}$ & TAF & $\begin{array}{l}\text { Wholesale and retail trade, } \\
\text { hotels, and restaurants }\end{array}$ & $\begin{array}{l}\text { BPS-Statistics Banjar } \\
\text { Municipality }\end{array}$ \\
\hline $\begin{array}{l}\text { Transportation and } \\
\text { communication }\end{array}$ & TC & $\begin{array}{l}\text { Transportation road, railway, } \\
\text { air, and } \\
\text { communication }\end{array}$ & $\begin{array}{l}\text { BPS-Statistics Banjar } \\
\text { Municipality }\end{array}$ \\
\hline $\begin{array}{l}\text { Finance and } \\
\text { business services }\end{array}$ & FBS & $\begin{array}{l}\text { Includes Finance, rent, and } \\
\text { businessservices }\end{array}$ & $\begin{array}{l}\text { BPS-Statistics Banjar } \\
\text { Municipality }\end{array}$ \\
\hline Other services & OS & Public and private services & $\begin{array}{l}\text { BPS-Statistics Banjar } \\
\text { Municipality }\end{array}$ \\
\hline
\end{tabular}

\section{RESEARCH METHODS}

There are plenty of methods that can describe a leading sector and the structure of the economy of a city. However, this paper primarily utilized LQ and SSA. In addition, to explore the main factors from the decentralization sectors that affected economic growth we utilized ordinary least square (OLS) regression analysis.

\subsection{Leading Sector Analysis}

To get a specific description of industrial concentration in an area (i.e., by decomposing where a product is in a particular geographical place) we comparing them to wider areas using LQ analysis which is commonly used as a quantitative technique in base economic theory (Moore et al., 2006). In terms of the changeability of the leading sector's calculation, this paper uses a formula, i.e., Eq. (1), used by several previous studies (Morrisey, 2014; Crawley et al., 2013; Riddington et al., 2006; Jahn, 2017). The starting point collects the distribution of GRDP at the constant market price from 2007 to 2016 and calculates it accordingly.

$$
L Q=\frac{g_{i}^{t} / g^{t}}{G_{i}^{t} / G^{t}}
$$

Where: $L Q$ is the value of the leading sector in one geographic area (note: $L Q>$ 1 is defined as the leading sector; $L Q<0$ is defined as a sector in deficit and the area might be relying on this sector from a different area; $L Q=0$ is defined as a sector only supply for the local area with no potential export); $g_{i}^{t}$ is the value of sector $i$ in one geographic area in the year $t ; g^{t}$ is the sum of all the sectors in the 
year $t ; G_{i}^{t}$ is the value of the sector $i$ in the regional geographic area in the year $t ; G^{t}$ is value of the whole sector in the regional geographic area in the year $t$.

The SSA is one method that is widely used and credited as a tool to understand political economy, retail analysis, and regional economy (Knudsen, 2000). A SSA is also applicable in its analysis to measure the implication of structural development in a country's international competitiveness-over time-when it was applied to export growth (Wilson et al., 2005). Despite the weakness of the method, since it does not explain economic growth patterns, SSA has been proven popular for almost half a century due to its very straightforward logic and interpretation (Jackson \& Haynes, 2009; Dogru \& Sirakaya-Turk, 2017). Three components makeup the SSA (i.e., regional share (RS), industrial mix (IM), and competitive share (CS)) formulated in Eq. (2).

$$
S_{i}=R S_{i}-
$$

Where: $S_{i}$ is the value of SSA for sector $i, R S_{i}$ is regional share represented by Eq. (3); $I M_{i}$ is a mix component in sector $i$ represented Eq. (4); $C S_{i}$ is a competitive component in sector $i$ represented Eq. (5).

$$
\begin{gathered}
R S_{i}=g_{i, t-n} * \frac{G_{t}-G_{t-n}}{G_{t-n}} \\
I M_{i}=g_{i, t-n} *\left(\frac{G_{i, t}-G_{i, t-n}}{G_{i, t-n}}-\frac{G_{t}-G_{i, t-n}}{G_{i, t-n}}\right) \\
C S_{i}=g_{i, t-n} *\left(\frac{g_{i, t}-g_{i, t-n}}{G_{i, t-n}}-\frac{G_{i, t}-G_{i, t-n}}{G_{i, t-n}}\right)
\end{gathered}
$$

Where: $g_{i}$ is the value of sector; $t$ is the year of last period of the research; $n$ is the sum of the research period.

\subsection{Regression Analysis}

Based on the reviewed literature, this study develops a linear regression model using OLS regression analysisi to determine variables that have a significant contribution to the economic growth of Banjar Municipality (Kowalski, 2000; Greene, 2012; Glodowska \& Pera, 2019). The variables used are components that the local government has authority over, that being: local government expenditure, local regulation, labor force, education facilities, and local road facilitation. These independent variables once pieced together formulate Eq. (6).

$$
\begin{gathered}
L n E G_{i t}=\alpha_{0}+\beta_{1} \ln E x+\beta_{2} \ln L R e g+\beta_{3} \ln L F \\
+\beta_{4} \ln E F+\beta_{5} \ln L R+\varepsilon
\end{gathered}
$$

Where: $E G$ is economic growth as a dependent variable; $\alpha_{0}$ is the intercept parameter; $\beta_{1}, . . \beta_{k}$ are regression parameters; $E x$ is local government expenditure; $L R e g$ is the local regulation; $E F$ is primary and secondary education facilities; $L R$ is the local road; $\varepsilon$ is the error term.

The significance test conducted also determined the value of the independent variable. Hence, R2 and adjusted R2 values that are closer to one are good indicators of high correlation and a pvalue indicating the degree of confidence is set to $5 \%$ or less. Next, a multicollinearity test was performed to determine if there was a correlation between the independent variables. If a correlation was present, then a variance inflation factor (VIF) of greater than ten would indicate a positive multicollinearity and the independent variable would yield affective.

\section{RESULTS}

The economic growth of Banjar Municipality was relatively stable during 
the research period, with minor positive and negative fluctuation pending the variable. An important lesson in retrospect of China's economic structure reminds us of similar results in that country's early years before its success as an economic force (Peng et al., 2017). In the first five years of Banjar Municipality's anonymity, the city's policy focused on infrastructure development (e.g., local government offices, public service facilities, and relating amenities). These initial investments proved useful and lay the groundwork for its potential growth.

\subsection{Potential Growth from Economic Sectors}

When Banjar Municipality was allocated as an autonomous region it had limited infrastructure, public facilities, and out-and- out authority (i.e., political clout) on its population. As such, it is important to recognize crucial urban planning requisites that consider availability of resources and ability to compete with other regions. Banjar Municipality does not have natural resources and, thus, its revenue comes from other economic sectors. In this study, LQ and SSA were used in terms of GRDP, broken down into sectors, from BPS-Statistics Banjar Municipality data (BPS-Statistic of Banjar Municipality, 2017).

The LQ result is illustrated in Table 2 in which three main potential economic sectors contribute to the development of the city, namely: (1) agriculture, livestock, forestry, and fishery; (2) trade, accommodation, and food business; and (3) finance and business services. Notably, other services also have a significant impact. Based on the result, agriculture, livestock, forestry, and fishery has the greatest potential for export. In terms of location, the Municipality is traversed by the Citanduy River which could be one of the specific reasons for a strong agricultural sector - acting like the backbone of the economy. Trade, accommodation, and food business as well as finance and business services also performed well as base sectors. Inference on their success, again, pinpoints on the Municipality's location in which the intersection national road to Central Java Province and the tourism area of Pangandaran Beach play an important role. The other services, noted, consist of public and private sector advancements such as health services that currently dominate the economic growth with the founding of the city's A-type hospital facility (i.e., one of the most modern hospitals in the region). In general, construction and building as well as transportation and communication were two sectors that experienced a decreasing trend in the tenyear study.

In terms of SSA, each economic sector was analyzed by calculating the GRDP of each sector using the overall regional sector score. Data originated from Banjar Municipality and West Java Province over a period of ten years from 2007 to 2016. The result of the SSA analysis can be seen in Table 3. 
Agus Supriyadi, et al. Sustainability Policy in Indonesia: Case Study ... | 36

Table 2. LQ Values for each Economics Sector

\begin{tabular}{|c|c|c|c|c|c|c|c|c|c|c|}
\hline $\begin{array}{c}\text { LQ } \\
\text { Variable }\end{array}$ & 2007 & 2008 & 2009 & 2010 & 2011 & 2012 & 2013 & 2014 & 2015 & 2016 \\
\hline Agr & 1.57 & 1.59 & 1.45 & 1.51 & 1.59 & 1.57 & 1.56 & 1.54 & 1.59 & 1.55 \\
\hline MC & 0.13 & 0.13 & 0.12 & 0.12 & 0.13 & 0.11 & 0.12 & 0.12 & 0.12 & 0.12 \\
\hline MI & 0.26 & 0.25 & 0.27 & 0.28 & 0.25 & 0.26 & 0.25 & 0.25 & 0.24 & 0.24 \\
\hline Cons & 1.54 & 1.54 & 1.56 & 1.47 & 1.18 & 1.17 & 1.19 & 1.19 & 1.16 & 1.15 \\
\hline EGW & 0.48 & 0.49 & 0.45 & 0.45 & 0.80 & 0.45 & 0.43 & 0.43 & 0.46 & 0.46 \\
\hline TAF & 1.62 & 1.67 & 1.60 & 1.94 & 1.54 & 1.63 & 1.66 & 1.66 & 1.64 & 1.64 \\
\hline TC & 1.65 & 1.72 & 1.62 & 1.45 & 1.88 & 1.15 & 1.16 & 1.17 & 1.18 & 1.17 \\
\hline FBS & 2.16 & 2.11 & 2.02 & 1.92 & 1.94 & 1.79 & 1.76 & 1.75 & 1.72 & 1.67 \\
\hline OS & 2.16 & 2.27 & 2.22 & 2.13 & 2.09 & 2.06 & 2.06 & 2.16 & 2.16 & 2.17 \\
\hline
\end{tabular}

Table 3. Comparative Advantage of SSA Values for each Economic Sector between 2007 and 2016

\begin{tabular}{|c|c|r|r|r|r|}
\hline Sector & LQ $^{\dagger}$ & RS & IM & CS & SSA total \\
\hline Agr & Yes & $144,960.41$ & $-1,717.99$ & $-111,798.69$ & $31,443.73$ \\
\hline MC & No & $3,256.11$ & $-5,444.92$ & $2,463.41$ & 274.59 \\
\hline MI & No & $119,449.19$ & $-6,483.90$ & $-74,696.55$ & $38,268.74$ \\
\hline Cons & No & $3,012.98$ & 486.20 & $-2,492.06$ & $1,007.54$ \\
\hline EGW & No & $99,828.02$ & $12,642.33$ & $-58,590.73$ & $53,879.62$ \\
\hline TAF & Yes & $330,510.67$ & $-28,907.31$ & $-155,001.84$ & $146,601.52$ \\
\hline TC & No & $88,763.09$ & $75,531.91$ & $-66,229.15$ & $98,065.85$ \\
\hline FBS & Yes & $73,581.70$ & $17,993.61$ & $-49,218.70$ & $42,356.62$ \\
\hline OS & Yes & $182,678.69$ & $45,039.53$ & $-112,341.86$ & $115,376.35$ \\
\hline
\end{tabular}

†Supporting sector of economic development; Source: Authors own elaboration

According to Table 3, it is can be said that all of the SSA totals retained a positive value, meaning those sectors developed a positive, contributing and absorbing, labor force. The highest contributing variable to economic growth and employment was trade, accommodation, and food business with 
$330,510.67$ of the total SSA value and the lowest was mining and quarrying with 274.59. Agriculture, livestock, forestry, and fishery; trade, accommodation, and food business; and other services have a significant positive value in the regional share equating to these contributing sectors as lead absorbers of employment and economic growth. These sectors, considered as first level sectors, that should be maintained. In the industrial mix, it can be highlighted that construction and building; electricity, gas, water supply, and water treatment; finance and business services; and other services have a general positive value. It is interesting to note, with the exception of mining and quarrying, none of the other sectors had a positive competitiveness when combined with a provincial level supply chain, meaning there were no noticeable specialties found Municipality-wide and no other autonomous entities (e.g., regions or cities) that could be can relied upon for economic growth.

\subsection{Regional Autonomy and Economic Growth Variables}

Based on the literature, this study examined influences that significantly contributed to the economic growth of Banjar Municipality. We applied five factors to model the OLS regression analysis. The factors were chosen based upon the local government authority's implementation of regional autonomy and its relating policy adjustments. The OLS regression analysis results are illustrated in Table 4.
The model was analyzed using Stata 15 software to check for correlative and determinative variable results and show if they are representative of reality. The result of the model showed that the multiple adjusted R-squared value was 0.8070 which is nearer to 1.0 - indicating an overall strong relationship. The process then checked the multicollinearity of every independent variable (i.e., a VIF < 10 meant there is no multi-collinearity in the regression model). Based on the result each factor had value $<10$, hence, concluding that the regression model had no multicollinearity for all of the independent variables.

\section{DISCUSSION}

For the ten-year study from 2007 to 2016, it can be deduced that the sectors that contributed to Banjar Municipality's economic development were agriculture, livestock, forestry, and fishery; trade, accommodation, and food business; finance and business services; and other services - in line with previous research conducted in Aceh Province (Kifli and Umami, 2017). The location of Banjar Municipality, the suburbs of West Java Province, yields this city closer to rural areas and, hence, subject to agricultural products and related outputs. Generally, the agriculture, livestock, forestry, and fishery sector have an essential role in economic growth; however, compared to other regions, the impact of the agricultural output is relatively insignificant since the city has a small geographical area. 
Table 4. OLS Regression Analysis

\begin{tabular}{|l|c|c|c|c|c|}
\hline $\begin{array}{l}\text { Independent } \\
\text { Variable }\end{array}$ & $\begin{array}{c}\text { Standard } \\
\text { Error }\end{array}$ & $\begin{array}{c}\text { Significance }(p- \\
\text { value }>t)\end{array}$ & R-squared & $\begin{array}{c}\text { Adjusted R- } \\
\text { squared }\end{array}$ & VIF \\
\hline Expenditure & 0.057035 & $0.090^{* *}$ & & & 5.68 \\
\hline Local regulation & 0.51662 & $0.034^{* *}$ & 0.9142 & 0.8070 & 3.28 \\
\hline Labor force & 0.470402 & 0.693 & & & \\
\hline Education facility & 1.571344 & $0.083^{* *}$ & & & \\
\hline Local road & 7.055934 & $0.040^{* *}$ & & & \\
\hline & & & & & \\
\hline
\end{tabular}

trepresents $t$ values; ${ }^{* *} 5 \%$ confidence intervals; Source: Authors own elaboration

Historically, before Banjar became an autonomous region, it was a district that became a trading center on the east-south border of West Java Province, especially the sale of agricultural products, where the traditional markets normally accommodate and sell agricultural products from surrounding As a new autonomous city, that is constructing massive infrastructure and public facilities, it can also be perceived that for the five-year period from 2007 to 2011 the construction and building sector provided a stronger portion to economic growth which declined in the latter five-year period (i.e., 2012-2017).
Another policy that is the focus of the local government is to give special attention to the village by providing financial assistance for infrastructure development and community empowerment, namely the provision of capital for village-owned enterprises. Infrastructure development carried out by the village government is encouraged to be labor intensive, which means that every development implementation as far as possible involves the local community resources. The policy carried out by the Banjar Municipality government was implemented long before the central government also finally launched a 
village assistance program. This policy is one of the positive effects of regional autonomy, because regions no longer build top-down but rather specific policies based on local wisdom and the most urgent needs according to each village in the region.

However, the result of SSA indicated that the construction and building sector still maintain the aggregate GRDP even though it was not considered a supporting sector of economic development. Despite the small share in the GDP, the construction and building sector shared a high number of employed labor, which strengthens previous research from Khan's Pakistan and Sitsabo's United Kingdom studies (Khan, 2008; Dlamini, 2012). Meanwhile, some nonreciprocal findings from South Africa (Dlamini, 2012) and Turkey (Berk \& Bicen, 2017) exhibit construction and building as an essential sector to economic growth.

According to the OLS regression analysis, local regulation and local road facilitation were two variables that contributed significantly and have a strong correlation to the economic growth during the ten-year period (i.e., $p$-values of 0.034 and 0.040, respectively). It can be inferred that local regulation offers positive value and effects to economic growth; in other words, the local government produces local regulatory precepts that give certainty to law and order (and in extension business confidence). One interesting policy adopted by the local authority is the postponement of the permit of establishment a new modern mini market since 2005, which has contributed to the survival of small retail stores. Although this policy is relatively challenged by investors in the modern mini market, and quite influential on the small number of investors interested in investing in or opening a business in Banjar,

it has succeeded in encouraging the growth of small stalls and new small businesses. This situation considered as one of a good example of what this new autonomous city has done about how they maintain their economic activities by defending small entrepreneurs from the onslaught of big entrepreneurs.

As such, regulation-based local knowledge also contributes significantly to the development of the city. In terms of local road facilitation, previous research has also detailed local road development as a good precedent to increasing economic growth via the movement of workers and market connections (Asher \& Novosad, 2019). Positive impacts from regulation are in line with research from the United States in which public policy is different in different areas, so that the service sector basically has an important role in the economy of this region jurisdictions. This affect has wide implications on business allocation and deregulatory effects on cutting the cost of production (Fisher, 1997) and moving product. However, to enlarge a comprehensive understanding of the economic development in Banjar Municipality, we would stress the importance of conducting a socioeconomic survey that could elucidate any regulatory differences in terms of local, provincial, and national level benefits-and extend the research to reciprocal countries concerned with similar urban-economic phenomena. 


\section{CONSLUSION}

In the development economics it is generally perceived that efficiency of allocation means more productive resources while sustainable growth is more in line with economic, social, political, and institutional mechanisms via public and private services (Todaro \& Smith,2012; Paczoski et al., 2019). The economic structure, in terms of structural change theory, focuses on the transformation from traditional subsistence agriculture to a modern urban way of life (Todaro \& Smith, 2012; Russo \& Cirella, 2019). This study used GRDP data with an underlying objective of determining what leading sectors contributed the most to economic growth since Banjar Municipality's issuance as a new autonomous city. The following conclusions were obtained from 2007 to 2016. Banjar Municipality relies heavily on the following sectors: agriculture, livestock, forestry, and fishery; trade, accommodation, and food business; finance and business services; and other (i.e., public and private) services-in that order. Thus, to accelerate economic growth, it is highly recommended these sectors continue to be properly facilitated within regional development and related policy plans. However, as noted with the exception of the mining and quarrying sector, the other sectors did not have a positive impact in terms of their competitiveness with other autonomous regions.

In this regards, innovative local government development in creating policy that would increase the specialty in local products in the leading sectors should be emphasized.

In terms of regional autonomy, the policy implementation process set in place by Banjar Municipality's local government will need to continue to assess and develop policy in several public areas and facilities. Local regulation, implemented in the region, should continue to focalize on protecting traditional market policy as well as lengthen, upgrade, and

maintain road infrastructure. Such regulation could include a community of practice approach (Cirella et al., 2018; Docherty, 2017) which would take into account local knowledge and consideration when piecing together city goals. If local policy expands local road infrastructure there would be an expectation of increased accessibility for the local inhabitants by way of mobility, doing business, and helping to protect the traditional market. New policies will need to be properly enforced and maintained for maximum economic success. In terms of sustainability, regional authorities will need to adjust and promote transitional steps to battering capacity, education, community knowhow, and policymaking skills (Darmawan, 2008). Hence, it is our recommendation, at this stage, that necessary central government intervention in terms of sustainability still be interplayed within the Municipality's policymaking outlook. 


\section{REFERENCES}

Akib, H., Wagianto, E., Daraba, D., \& Niswaty, R. (2019). Shift-share analysis of the development of local competence as a basis for interregional cooperation in West Sulawesi Province, Indonesia. Journal of Legal, Ethical and Regulatory Issues, 22(1), 1-11.

Ali, M., Egbetokun, A., \& Memon, M. H. (2018). Human capital, social capabilities and economic growth. Economies, 6(1), 2.

Andayani, K. (2018). Economic base determination and influence of several variables against contributions percentage of the GDRP in Aceh Besar district. MSEE, 352(1), 012053.

Arent, D. J., Tol, R. S., Faust, E., Hella, J. P., Kumar, S., Strzepek, K. M., ... \& Xu, H. (2015). Key economic sectors and services. In Climate Change 2014 Impacts, Adaptation and Vulnerability: Part A: Global and Sectoral Aspects, 659-708.

Asher, S., \& Novosad, P. (2019). Rural Roads and Local Economic Development Online Appendix.

Asian Development Bank., “Asian Development Bank Support for Decentralization in Indonesia." Special Evaluation Study, 2010.

Berk, N., \& Biçen, S. (2017, April). Causality between the construction sector and GDP growth in emerging countries: the case of Turkey. In 10th Annual International Conference on Mediterranean Studies, 10-13.

Bose, N., Haque, M. E., \& Osborn, D. R. (2007). Public expenditure and economic growth: A disaggregated analysis for developing countries. The Manchester School, 75(5), 533-556.

BPS-Statistic of Banjar Municipality. 2017, Banjar Municipality in Figures. Banjar Mucicipality: BPS- Statistic Banjar Municipality.

Cirella, G. T., Iyalomhe, F. O., Jensen, A., \& Akiyode, O. O. (2018). Exploring community of practice in Uganda's public sector: environmental impact assessment case study. Sustainability, 10(7), 2502.

Costanza, R., Hart, M., Talberth, J., \& Posner, S. (2009). Beyond GDP: The need for new measures of progress. The pardee papers.

Crawley, A., Beynon, M., \& Munday, M. (2013). Making location quotients more relevant as a policy aid in regional spatial analysis. Urban Studies, 50(9), 18541869.

Daly, M. C., \& Regev, T. (2007). Labor force participation and the prospects for US growth. FRBSF Economic Letter. 
Darmawan, R. E. D. (2008). The practices of decentralization in Indonesia and its implication on local competitiveness (Master's thesis, University of Twente).

Dlamini, S. (2012, June). Relationship of construction sector to economic growth. In International Congress on Construction Management, Canada.

Docherty, M. A. (2017). Action research: a process for developing professional capacity within a community of practice. International Journal of Knowledge Management Studies, 8(1-2), 74-82.

Dogru, T., \& Sirakaya-Turk, E. (2017). Engines of tourism's growth: An examination of efficacy of shift-share regression analysis in South Carolina. Tourism Management, 58, 205-214.

Drucker, J., Kim, G., \& Weber, R. (2019). Did incentives help municipalities recover from the Great Recession? Evidence from Midwestern cities. Growth and Change, 50(3), 894-925.

Dunn Jr, E. S. (1960). A statistical and analytical technique for regional analysis. Papers in Regional Science, 6(1), 97-112.

Endaryanto, T., Firdaus, M., Siregar, H., \& Budiman Hakim, D. (2015). The impact of regional expansion on economic structure: A case study in Lampung province, Indonesia. International Journal of Sciences: Basic and Applied Research (IJSBAR), 23(2), 1-18.

Evans, G. K. (2008). Spatial shift-share analysis of the leisure and hospitality sector on the Gulf Coast following hurricane Katrina (No. 1368-2016-108539).

Fagerberg, J. (2000). Technological progress, structural change and productivity growth: a comparative study. Structural change and economic dynamics, 11(4), 393-411.

Fan, S., \& Chan-Kang, C. (2005). Road development, economic growth, and poverty reduction in China, 12. Intl Food Policy Res Inst.

Feriyanto, N. (2014). Determinant of gross regional domestic product (GRDP) in Yogyakarta special province. Economic Journal of Emerging Markets, 6(2), 131140.

Fernández, M. M., \& Menéndez, A. J. L. (2005). The spatial shift-share analysis-new developments and some findings for the Spanish case.

Fisher, R. C. (1997). The effects of state and local public services on economic development. New England Economic Review, 53-66.

Głodowska, A., \& Pera, B. (2019). On the Relationship between Economic Integration, Business Environment and Real Convergence: The Experience of the CEE Countries. Economies, 7(2), 54. 
Goschin, Z. (2014). Regional growth in Romania after its accession to EU: a shift-share analysis approach. Procedia Economics and Finance, 15, 169-175.

Greene, William H. Econometric Analysis, 7th Edition. 7th ed. Harlow: Pearson Education Limited. 2012., 2.

Hu, W., \& Wang, R. (2019). Which Chinese cities are more inclusive and why?. Cities, 86, 51-61.

Jahn, M. (2017). Extending the FLQ formula: a location quotient-based interregional input-output framework. Regional Studies, 51(10), 1518-1529.

Jackson, R. W., \& Haynes, K. E. (2009). Shift-Share Analysis. International Encyclopedia of Human Geography, 125-131.

Johnston, A., \& Huggins, R. (2018). Regional growth dynamics in the service sector: The determinants of employment change in UK regions, 1971-2005. Growth and change, 49(1), 71-96.

Kelly, Roy, "Strengthening the Revenue Side." In Fiscal Decentralization in Indonesia a Decade after Big Bang, edited by Directorate General of Fiscal Balance Ministry of Finance Republic of Indonesia, 2012, 173-204.

Khan, R. A. (2008, August). Role of construction sector in economic growth: Empirical evidence from Pakistan economy. In Proceedings of the First International Conference on Construction in Developing Countries (ICCIDC), Karachi, Pakistan, 279-290.

Khusaini, M. (2015). A shift-share analysis on regional competitiveness-a case of Banyuwangi district, East Java, Indonesia. Procedia-Social and Behavioral Sciences, 211, 738-744.

Kifli, F. W., \& Umami, A. (2017). Contribution of Economic Sector and Agricultural Development to Support Food Security in North Sumatra Province. Advanced Science Letters, 23(7), 6428-6431.

Knudsen, D. C. (2000). Shift-share analysis: further examination of models for the description of economic change. Socio-Economic Planning Sciences, 34(3), 177198.

Kowalski, E. (2000). Determinants of economic growth in East Asia: A linear regression model. Honors Projects, 74.

Kristiawan, K., AR, N. H., Soemarno, S., \& Tyasmoro, S. Y. (2016). Leading product development of fruits using location quotient in Tuban regency. IOSR Journal of Agriculture and Veterinary Science, 9(8), 81-84. 
Lankauskienė, T., \& Tvaronavičienè, M. (2013). Economic sector performance and growth: contemporary approaches in the context of sustainable development. Intellectual economics, 7(3), 355-374.

Liao, L., Du, M., Wang, B., \& Yu, Y. (2019). The impact of educational investment on sustainable economic growth in Guangdong, China: a cointegration and causality analysis. Sustainability, 11(3), 766.

Liu, J., Tang, J., Zhou, B., \& Liang, Z. (2018). The effect of governance quality on economic growth: Based on China's provincial panel data. Economies, 6(4), 56.

Mallick, J. (2017). Structural change and productivity growth in India and the People's Republic of China.

Masaki, T. (2018). The impact of intergovernmental transfers on local revenue generation in Sub-Saharan Africa: Evidence from Tanzania. World Development, 106, 173-186.

Miller, M. A. (2013). Decentralizing I ndonesian City Spaces as New 'Centers'. International Journal of Urban and Regional Research, 37(3), 834-848.

Mogues, T., \& Benin, S. (2012). Do external grants to district governments discourage own revenue generation? A look at local public finance dynamics in Ghana. World Development, 40(5), 1054-1067.

Moore, T., Meck, S., \& Ebenhoh, J. (2006). An economic development toolbox: strategies and methods, 541.

Morrissey, K. (2014). Producing regional production multipliers for Irish marine sector policy: A location quotient approach. Ocean $\mathcal{E}$ coastal management, 91, 5864.

Noisirifan, De Fretes Pieter, "Analysis of Leading Sector (Lq), Structure of Economy (Shift Share), and Projection of GRDP Papua Province 2018." Develop, 1(2) 2018.

Nosier, S., \& El-Karamani, A. (2018). The Indirect Effect of Democracy on Economic Growth in the MENA Region (1990-2015). Economies, 6(4), 61.

Oates, W. E. (1993). Fiscal decentralization and economic development. National tax journal, 46(2), 237-243.

Paczoski, A., Abebe, S. T., \& Cirella, G. T. (2019). Debt and Deficit Growth Rate Reporting for Post-Communist European Union Member States. Social Sciences, 8(6), 173.

Paganelli, M. P. (2006). Adam Smith: Why Decentralized Systems?. The Adam Smith Review, 2, 201. 
Peng, C., Song, M., \& Han, F. (2017). Urban economic structure, technological externalities, and intensive land use in China. Journal of Cleaner Production, 152, 47-62.

Riddington, G., Gibson, H., \& Anderson, J. (2006). Comparison of gravity model, survey and location quotient-based local area tables and multipliers. Regional Studies, 40(9), 1069-1081.

Rigby, D. L., \& Anderson, W. P. (1993). Employment change, growth and productivity in Canadian manufacturing: An extension and application of shift-share analysis. Canadian Journal of Regional Science, 16(1), 69-88.

Romyen, A., Liu, J., Sriboonchitta, S., Cherdchom, P., \& Prommee, P. (2019). Assessing Regional Economic Performance in the Southern Thailand Special Economic Zone Using a Vine-COPAR Model. Economies, 7(2), 30.

Russo, A., \& Cirella, G. T. (2019). Edible urbanism 5.0. Palgrave communications, 5(1), 1 9.

Sobari, A. (2011). “The Impact of Fiscal Decentralization to the Regional SocioEconomic Development in Indonesia." Bogor Agricultural University. Bogor Agricultural University.

Sondakh, L., \& Jones, G. (2003). An economic survey of northern Sulawesi: turning weaknesses into strengths under regional autonomy. Bulletin of Indonesian Economic Studies, 39(3), 273-302.

Sukamdi. (2014). Struggling out of recession: The influence of crisis on economic performance and welfare in Java. Bulletin of Indonesian Economic Studies, 50(2), 295-296.

Supriyadi, A., Wang, T., Chu, S., Ma, T., Shaumirahman, R. G., \& Cirella, G. T. (2020). Urbanization and population change: Banjar Municipality. In Sustainable Human-Nature Relations, 205-223.

Suryadarma, D., Suryahadi, A., \& Sumarto, S. (2013). Sectoral growth and job creation: Evidence from Indonesia. Journal of International Development, 25(4), 549-561.

Suryahadi, A., Hadiwidjaja, G., \& Sumarto, S. (2012). Economic growth and poverty reduction in Indonesia before and after the Asian financial crisis. Bulletin of Indonesian Economic Studies, 48(2), 209-227.

Suryani, G. (2015). Regional Financial Autonomy and The Economic Growth In Indonesia. Bulletin of Monetary Economics and Banking, 18(2), 1-22.

Todaro, M. P., \& Smith, S. C. (2012). Economic development. Edited by Donna Battista and David Alexander. 12th ed. New Jersey: PEARSON, 2015.

Wagner, A. (1890). Finanzwissenchaft, Winter, CF, Leipzig. 
Wilson, P., Ping, T. S., \& Robinson, E. (2005). Assessing Singapore's export competitiveness through dynamic shift-share analysis. ASEAN Economic Bulletin, 160-185.

Zhu, S., Wu, Q. J., \& Wang, Y. (2011, September). Impact of labor force on China's economic growth based on grey metabolic GM $(1,1)$ model. In Proceedings of 2011 IEEE International Conference on Grey Systems and Intelligent Services, 262265. 